2009-01-01

\title{
Land use Planning in Ireland: a Life Cycle Energy Analysis of Recent Residential Development in the Greater Dublin Area
}

Aidan Duffy

Technological University Dublin, aidan.duffy@tudublin.ie

Follow this and additional works at: https://arrow.tudublin.ie/engschcivart

Part of the Civil and Environmental Engineering Commons

\section{Recommended Citation}

Duffy, A.: Land use planning in Ireland:a life cycle energy analysis of recent residential development in the Greater Dublin area. International Journal of Life Cycle Assessment, Vol.14, 3, 2009, pp.257-267.

doi:10.1007/s11367-009-0059-7

This Article is brought to you for free and open access by the School of Civil and Structural Engineering at ARROW@TU Dublin. It has been accepted for inclusion in Articles by an authorized administrator of ARROW@TU Dublin. For more information, please contact arrow.admin@tudublin.ie, aisling.coyne@tudublin.ie, gerard.connolly@tudublin.ie.

Funder: Dublin Institute of Technology's Research

Support Unit.

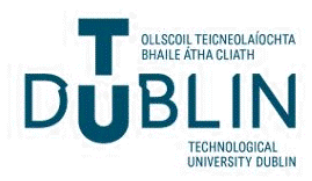




\section{Land use planning in Ireland-a life cycle energy analysis of recent residential development in the Greater Dublin Area}

\section{Abstract}

Background, aim, and scope One third of the total housing stock in the Republic of Ireland has been built in 10 years up to and including 2006 and of this approximately 34\% was built in the Greater Dublin Area (GDA). Much of the housing was low-density with poor public transport links leading to doubts over its sustainability-particularly in terms of energy use. Although the country is committed to reducing greenhouse gases to $13 \%$ above 1990 levels by the period 2008-2012, by 2005, emissions were already $25.4 \%$ higher than the baseline and current projections are that this figure will rise to $37 \%$ over the period. The residential sector is estimated to contribute to approximately $24.5 \%$ of energy-related $\mathrm{CO}_{2}$ emissions. This paper estimates total emissions from residential developments in the GDA constructed between 1997 and 2006.

Materials and methods Carbon dioxide equivalent $\left(\mathrm{CO}_{2}\right)$ emissions are estimated using a life cycle assessment approach over a 100 -year building lifespan and employing process, input-output and hybrid energy techniques. Life cycle stages include: construction, operation, transport, maintenance and demolition. The main data sources include: national population and industry census data, household travel survey data, residential energy performance surveys and national accounts. The GDA was split into four zones each encompassing development at increas-

Responsible editor: Llorenç Milà i Canals

A. Duffy $(\bowtie)$

School of Civil and Building Services Engineering,

Dublin Institute of Technology,

Bolton Street,

Dublin 1, Ireland

e-mail: aidan.duffy@dit.ie ing radii from Dublin's city centre, namely: city centre, suburbs, exurbs and commuter towns.

Results Per capita $\mathrm{CO}_{2}$ life cycle emissions in the GDA were found to be approximately $50-55 \%$ greater in the exurbs and commuter towns than in the city centre. Of the five life cycle stages studied, operational energy requirements (predominantly space heating and hot water, but including power) contributed most significantly to emissions $(68 \%)$, followed by transport (17\%), construction $(9 \%)$ and maintenance/renovation (6\%).

Discussion Operating emissions from dwellings in the commuter town and extra-urban zones were almost twice those in the city centre both due to larger dwelling sizes and the predominance of detached and semi-detached dwellings (with large amounts of exposed walls) in the former and the prevalence of smaller apartments in the latter. Car use was most pronounced in the zones furthest from the city centre where per capita emissions were almost twice those of residents in the city centre. Despite their smaller size, the per capita construction $\mathrm{CO}_{2}$ emissions of apartments were approximately one third greater than for low-rise dwellings due to the greater energy intensity of the structure. However, this difference was more than compensated for by the significantly lower operational emissions referred to above. Conclusions In 2006, recurrent $\mathrm{CO}_{2}$ emissions (operational, transport and maintenance) from dwellings built in the GDA over the ten preceding years were 2,108 kt while construction-related emissions in that year were $1,325 \mathrm{kt}$ giving a total contribution from the residential sector of $3,434 \mathrm{kt} \mathrm{CO} /$ annum-representing $4.9 \%$ of national emissions for that year. Had the development policy prescribed 'city centre'-type development and transport modes, then emissions for the year 2006 would have been 2,892 kt $\mathrm{CO}_{2}$-a reduction of almost $16 \%$ over the actual figure. However, in this scenario recurrent emissions would have 
been reduced to $1,417 \mathrm{kt} \mathrm{CO}_{2}-\mathrm{a}$ reduction of $33 \%$ over actual levels.

Recommendations and perspectives This study supports Irish and international governments' policies aimed at curbing $\mathrm{CO}_{2}$ emissions from the domestic sector which focus primarily on reducing operational emissions from new and existing housing through design and construction improvements. However, it demonstrates that significant reductions in operational emissions are associated with high-density residential development with modest floor areas. Furthermore, it highlights the scope for transport emissions' reductions through better spatial planning leading to reduced car travel.

Keywords Carbon dioxide equivalent $\cdot \mathrm{CO}_{2} \cdot$ Domestic dwellings $\cdot$ Embodied energy $\cdot$ Energy $\cdot$ Greenhouse gas emissions $\cdot$ Life cycle assessment $\cdot$ Spatial planning

\section{Background, aim, and scope}

At the end of 2006 there were 1,835,515 domestic dwellings in the Republic of Ireland (CSO 2007a). Of these, 607,961 -representing one third of the total housing stock-were built in the 10 years up to and including that year (Fig. 1). Approximately $34 \%$ of this new housing was built in Dublin and the greater Dublin region, much of which was low-density with poor public transport links. Indeed, much of the housing development in Ireland can be characterised as 'once-off' or low-density located outside urban centres: over one third of the development comprised detached houses, $44 \%$ were semi-detached or terraced housing units and only one fifth were apartments. In contrast, multi-family dwellings account for almost half of Europe's housing stock (Netherlands Ministry of Housing, Spatial Planning and the Environment 2004). The adoption

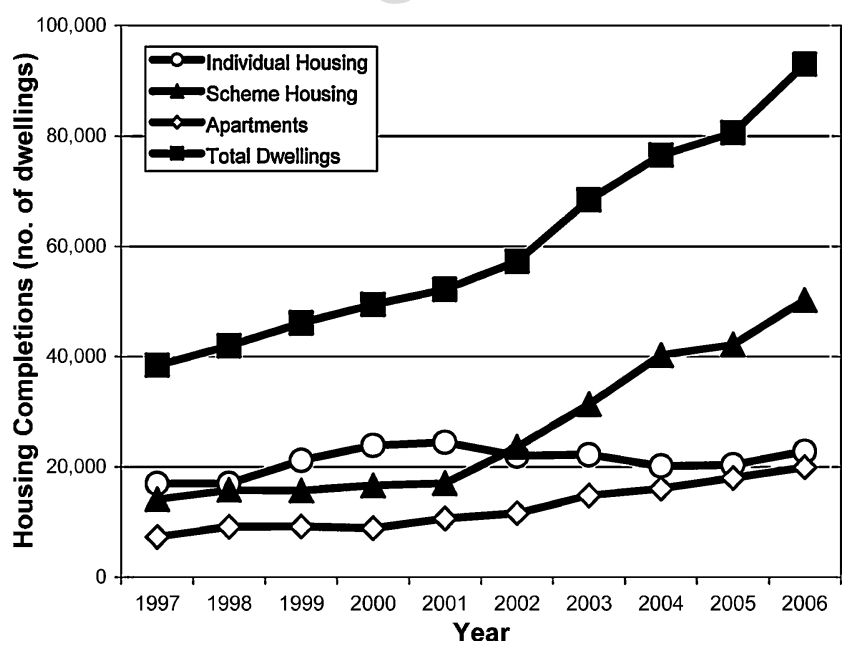

Fig. 1 Annual housing completions in Ireland 1997-2006 in Ireland of such low density suburban and extra-urban development policies may have resulted in increased greenhouse gas emissions when compared with higher density urban developments.

Ireland's energy emissions' performance is poor by international standards: in 2004, energy use per capita was $3,870 \mathrm{~kg}$ of oil equivalent (kgoe) and associated greenhouse gas emissions were $10,589 \mathrm{~kg}$. This compares unfavourably with EU27 figures of 3,689 kgoe and $8,180 \mathrm{~kg}$, respectively (Eurostat 2007). Although the country has committed to reducing greenhouse gases to $13 \%$ above 1990 levels by the period 2008-2012, by 2005, emissions were already $25.4 \%$ higher than the baseline (EPA 2007) and current projections are that this figure will rise to $37 \%$ over the period. Residential energy use accounted for almost one quarter of total national fuel consumption in 2005 of which almost $75 \%$ is used for space heating and hot water (Howley et al. 2006).

The impact of a domestic development on greenhouse gas emissions is related to the quantity and carbon content of the energy required over its lifetime. For example, two similar buildings with different passive thermal performances will consume different amounts of energy: one will emit more greenhouse gases than the other. Identical buildings powered by fuels with different carbon contents (for example, biomass- versus oil-fuelled boilers) will also have differing impacts. The energy impact of a domestic development over its entire life cycle can be viewed as the sum of this operational energy use together with the energy needed to produce and maintain it, demolish it as well as the energy required to travel to and from it. Similarly, the $\mathrm{CO}_{2}$ impact is the global warming potentialweighted sum of greenhouses gases (predominantly carbon dioxide, nitrous oxide and methane) emitted by this energy use.

Australian literature suggests that the average energy required to produce a house in that country is approximately $5 \mathrm{GJ} / \mathrm{m}^{2}$ producing some 0.49 tonnes $/ \mathrm{m}^{2}$ floor area of carbon dioxide (CSIRO 2007) based on Australian emissions' intensities. This is referred to as 'embodied energy' and theoretically includes all direct and indirect production energy inputs such as construction, material production, raw material extraction and associated services. The average floor area of a domestic dwelling in Ireland in 2004 was $112 \mathrm{~m}^{2}$ (SEI 2005) and applying the Australian data, this gives a per-dwelling embodied energy of $560 \mathrm{GJ}$ and emissions of 55 tonnes of carbon dioxide $\left(\mathrm{CO}_{2}\right)$. Assuming a 100-year building lifespan, this is equal to annualised emissions of 0.55 tonnes of $\mathrm{CO}_{2}$ and 5.6 GJ of energy use. Although these figures are rough estimates - since the Australian embodied energies are likely to differ from those in Ireland (no Irish data are available at the time of writing) — when used with the
103

104

105

106

107

108

109

110

111

112

113

114

115

116

117

118

119

120

121

122

123

124

125

126

127

128

129

130

131

132

133

134

135

136

137

138

139

140

141

142

143

144

145

146

147

148

149

150

151

152

153

154

155 
operational and travel data below, they indicate the relative importance of embodied energy in the life cycle of a domestic building and will assist in the development of the life cycle assessment (LCA) methodology described in this paper.

In 2004, the mean energy use per Irish dwelling was $88 \mathrm{GJ}$ resulting in the emission of 8.2 tonnes of $\mathrm{CO}_{2}$ per annum. Some $79 \%$ of energy use was in the form of direct fossil fuel consumption, the remainder was electricity (SEI 2005).

In 2006, the Irish transport sector consumed 213,000 TJ of energy and emitted 15,273 kt of $\mathrm{CO}_{2}$ (SEI 2006) of which $40 \%$ was attributable to private cars (SEI 2004). In the same year, there were 1,469,521 households in Ireland (CSO 2007b) giving average annual transport-related $\mathrm{CO}_{2}$ and energy use figures of 4.2 tonnes and 58 GJ per dwelling, respectively. This approximation overestimates the direct energy inputs associated with moving to and from a domestic dwelling since many private car trips would be used for other purposes, although it ignores indirect energy inputs such as product development and manufacturing.

Little data are available on the maintenance-related energy requirements of domestic dwellings and associated emissions. Figures for the refurbishment and repair of office buildings are reported to lie in the range of 0.17 to $0.34 \mathrm{GJ} /$ $\mathrm{m}^{2}$ (Yohanis and Norton 2002). Taking the lower figuresince office refurbishment is likely to be more energyintensive than domestic refurbishment - and assuming an interval between refurbishments of 7 years, the annual maintenance-related energy intensity for an average Irish house is $2.72 \mathrm{GJ} / \mathrm{m}^{2}$ with associated emissions of $0.23 \mathrm{t}$ $\mathrm{CO}_{2}$. However, even the use of the lower office refurbishment energy intensity figure may overestimate domestic emissions.

Based on these data, the total approximate annualised life cycle energy requirement for an average domestic Irish dwelling is $154.3 \mathrm{GJ}$ emitting 13.2 tonnes of $\mathrm{CO}_{2}$. Transport and operation dominate life cycle energy requirements (38\% and 56\% respectively) and $\mathrm{CO}_{2}$ emissions (32\% and $62 \%$ respectively). Based on these preliminary results, the methodology outlined in this paper focuses therefore to a greater extent on operational and transport energy use and emissions than on construction, maintenance and demolition.

The objectives of this study are to: determine the wholelife energy and $\mathrm{CO}_{2}$ intensities of dwellings built in the Greater Dublin Area (GDA) between 1997 and 2006; assess the relative impact of different life cycle stages on energy use and $\mathrm{CO}_{2}$ emissions; and quantify and compare the impact of urban, suburban and extra-urban residential developments in and around Dublin on national energyrelated greenhouse gas emissions.

\section{Materials and methods}

209

Life cycle assessment (LCA) was used to determine energy use and carbon dioxide emissions for all stages of a residential development including:

- construction;

- operation including heating, hot water, lighting and small power loads;

- travel to and from the development;

- maintenance; and

- demolition

The study only considered the greenhouse gas impacts associated with energy use and ignored wider environmental impacts such as resource depletion, groundwater pollution and habitat loss. $\mathrm{CO}_{2}$ emissions only were calculated since these data are easily available. However, since $\mathrm{CO}_{2}$ accounts for only $93 \%$ of non-agricultural greenhouse gas (GHG) emissions in Ireland by global warming potential (CSO, 2007c), resulting figures were divided by 0.93 to correct for unaccounted energy-related GHG emissions (such as $\mathrm{N}_{2} \mathrm{O}$ and $\mathrm{CH} 4$ ) to estimate total emissions in $\mathrm{CO}_{2}$ equivalent (referred to hereafter simply as $\mathrm{CO}_{2}$ ).

Energy requirements and emissions for each of the life stages of the residential development were determined using process, input-output or hybrid process analysis depending on data availability. These methodologies are described by inter alia Crawford (2007) and Bullard et al. (1978).

\subsection{Developments}

Two developments were selected to represent typical recent residential developments in the Greater Dublin Area (a term which is used to describe the city and county of Dublin as well as the adjacent counties of Kildare, Meath and Wicklow) which are described below.

A high density mixed-use urban development in the city of Dublin comprising 300 apartments of one, two and three bedrooms with a total gross floor area of $22,500 \mathrm{~m}^{2}$. The scheme also contains retail and office units.

A development of 118 two-storey detached, semidetached and terraced houses on a 5.7 ha site outside the city comprising detached, semi-detached and terraced houses ranging in size from three to five bedrooms.

\subsection{Construction}

The energy embodied in the above developments was determined using hybrid process analysis up to the point of completion of the construction process by the contractor and hand over to the new resident. This required material-
210

211

212

213

214

215

216

217

218

219

220

221

222

223

224

225

226

227

228

229

230

231

232

233

234

235

236

238

239

240

241

242

243

244

245

246

247

248

249

250

252

253

254

255 
specific energy intensities (Hammond and Jones 2006) which were used in conjunction with national input-output tables (CSO 2006a) to quantify the total upstream and direct energy requirements for the building. Upstream energy requirements might include raw materials' extraction and building materials' manufacturing; direct energy relates to energy expended during the construction process itself.

Bills of quantities detailing material quantities and prices were obtained from the contractor who built the schemes. Where possible, materials were identified, characterised and process energy intensities applied. Energy intensities of unidentified expenditure were estimated using Irish construction sector energy intensities derived from national input-output tables, mean national energy tariffs, primary energy factors and disaggregation coefficients (Acquaye et al. 2008). An integral part of this methodology involved calculating a carbon dioxide equivalent intensity based on the mix of fuels used.

\subsection{Transport}

Transport emissions for all trips to and from dwellings were calculated based on data from the Dublin Transportation Office's 2006 Household Survey (DTO 2006) of approximately 2,500 households in the Greater Dublin Area. The survey was carried out over a 1-week period where participants kept a detailed log of all movements to and from their dwellings. Relevant variables were extracted from the database which included:

- mode of transport (for example train, rapid rail, tram, bus, truck, van, car, taxi, motorbike, running, walking);

- number of trips made;

- trip distances; and

- trip duration

It is accepted that development density and land-use mix are inversely related to household-related travel distances and vehicle emissions (Frank et al. 2000; Næss 2006; Newman and Kenworthy 1999). Moreover, the distance of a residence from concentrated employment and recreational areas (typically a city centre) affects both transport mode (DTO 2006) and travel distance and, therefore, fuel consumption and $\mathrm{CO}_{2}$ emissions. In order to capture the effects of density and distance to urban centres, the Greater Dublin Area Household Survey data were therefore divided into four zones of increasing distance from the city centre (Fig. 2). These are:

Zone 1 City Centre which is roughly bounded by two canals and the inner ring roads to the north and south giving a radius of up to $3.0 \mathrm{~km}$ around the city;

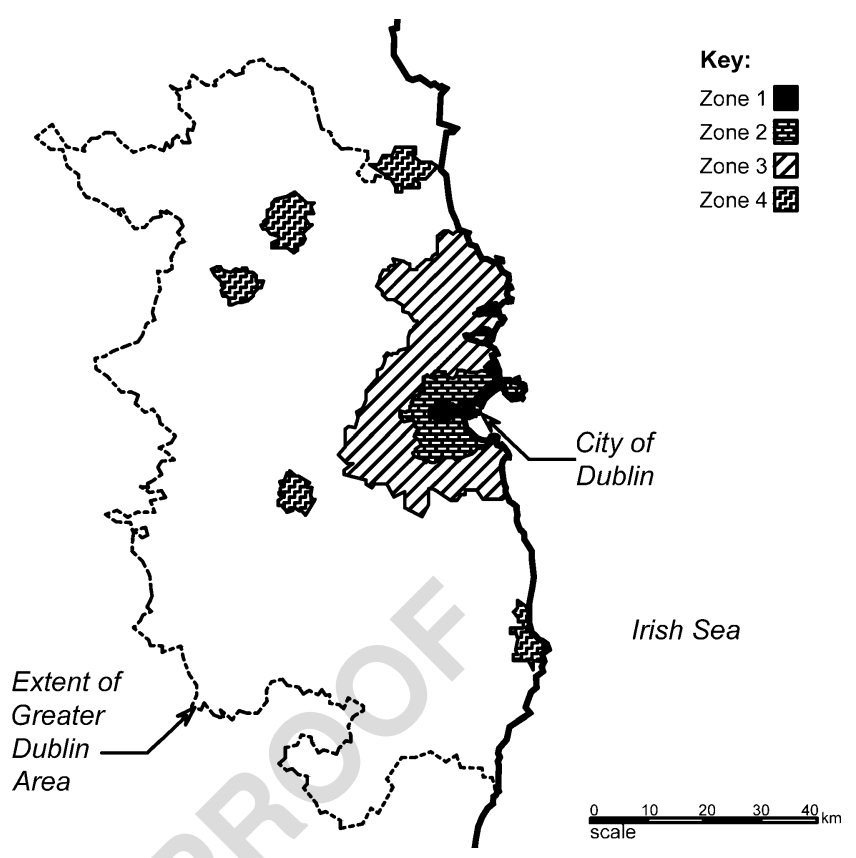

Fig. 2 Map of the Greater Dublin Area (GDA) showing the zones analysed

Zone 2 Suburbs which are located between the City Centre and the M50 motorway ring road at a radius of approximately $9.0 \mathrm{~km}$ around the city;

Zone 3 Exurbs covering the low density urban areas in the 309 remainder of county Dublin located outside the M50 incorporating many of the closer commuter towns at a radius of 15 to $30 \mathrm{~km}$ from the centre; and

Zone 4 Commuter towns of Drogheda (42 $\mathrm{km}$ from the centre), Navan (45 km), Enfield (40 km), Naas $(31 \mathrm{~km})$ and Wicklow $(43 \mathrm{~km})$.

Data were then analysed by zone to determine the total number of trips by mode of transport and total annualised modal distances travelled. Mean data were then calculated on a per household and per capita basis.

Fuel consumption and $\mathrm{CO}_{2}$ emissions data were calculated in the following ways:

no carbon dioxide emissions or fuel consumption was attributed to walking, running or cycling. This assumes that the energy and $\mathrm{CO}_{2}$ embodied in equipment such as footwear, bicycles, special clothing and helmets is negligible compared to that embodied in other forms of transport. The food requirements of individuals are outside the LCA boundary in all cases.

aeroplane, train, rapid rail transit, tram, bus, mini-bus, truck and motorbike energy uses and emissions were calculated using published average emissions per person kilometre (Cox and Hickman 1998; Davies
318 
Int J Life Cycle Assess

and Diegel 2007). Trains, buses, mini-buses and trucks were assumed to be diesel-fuelled while DART (a rapid rail system) and LUAS (a tram system) use electricity only. The average fuel consumption and carbon dioxide emissions data used in the analysis is presented in Table 1.

Since emissions from cars were expected to predominate, these were calculated in the more detailed manner described below.

Engine size and fuel type (diesel/petrol) distributions were determined using 2005 local government car registration data and a weighted mean engine size was calculated for both fuel types.

Mean fuel consumption was calculated for this engine size based on published data and speed-related efficiencies (Davies and Diegel 2007) were combined to give an equation for fuel consumptions for the weighted mean engine size (calculated above) at different speeds.

Average speeds for all car trips were calculated and fuel consumption determined using the fuel consumption to speed relationship.

This represents the fuel consumed only and does not consider the full life-cycle energy use of the car. Research by Castro et al. (2003) suggests that direct fuel consumption represents approximately $95 \%$ of the total life cycle energy requirements of a car and the results were adjusted accordingly. In the absence of equivalent life cycle assessment literature for other modes of transport, this figure was also applied to buses, trains, vans, trucks and motorbikes.

\subsection{Operation}

Operational energy requirements were quantified using the Energy Performance Survey of Irish Housing undertaken jointly by Sustainable Energy Ireland and CODEMA between 2004 and 2005. This study involved a detailed survey of the energy use characteristics of dwellings in Ireland and covered a range of construction types, ages and occupancy patterns. Relevant survey data were selected to be representative of the development types chosen here, in particular:

Data in the fields 'Detached', 'Semi-Detached', 'Terraced' and 'Purpose-Built Apartment' were incor- porated whereas, 'Converted Apartment' and 'Other' 377 were ignored and

Developments built since 1997 were included since different Building Regulations and energy performance standards pertained prior to this date and would not have been representative of the 1997-2006 housing stock. However, a lack of data for apartments necessitated the use of pre-1997 data which would have overestimated energy use and emissions to some extent.

Mean annualised energy use and carbon dioxide emissions data were calculated for the reduced sample of 59 dwellings based on recorded fuel mixes and quantities and these were validated against Scottish data. Data were converted from per-dwelling to per capita by dividing by the average number of persons per private household for the county or city as listed in the 2006 national census (CSO 2007a).

\subsection{Maintenance and demolition}

Maintenance requirements were determined using inputoutput analysis. Total expenditure for Irish housing repair, maintenance and improvements for the year 2004 were used (CSO 2006b) together with the energy intensity for the construction sector and total existing housing units for the period to determine the average annual domestic dwelling maintenance energy use.

Demolition costs were calculated using input-output analysis employing data from the 2004 Census of Building Construction (CSO 2006c). Turnover and input figures for Nace 45.1 'Site preparation, demolition and wrecking of buildings, earth moving, test drilling and boring' were used to determine energy intensities and these were used with 2004 published demolition costs (Davis Langdon and Everest 2004) to determine demolition energy requirements.

\section{Results and discussion}

\subsection{Construction}

Figure 3 shows the embodied $\mathrm{CO}_{2}$ emissions per dwelling. It can be seen that detached dwellings were found to have
Table 1 Average fuel consumptions and $\mathrm{CO}_{2}$ emissions for various modes of transport excluding cars (source: EEA 2003)

\begin{tabular}{lcc}
\hline Mode & Fuel consumption (grams oil equivalent/passenger km) & $\mathrm{CO}_{2}$ emissions (g/passenger km) \\
\hline Bus & 23 & 73 \\
Truck & 97 & 216 \\
Motorbike & 36 & 104 \\
Rail & 20 & 44 \\
\hline
\end{tabular}




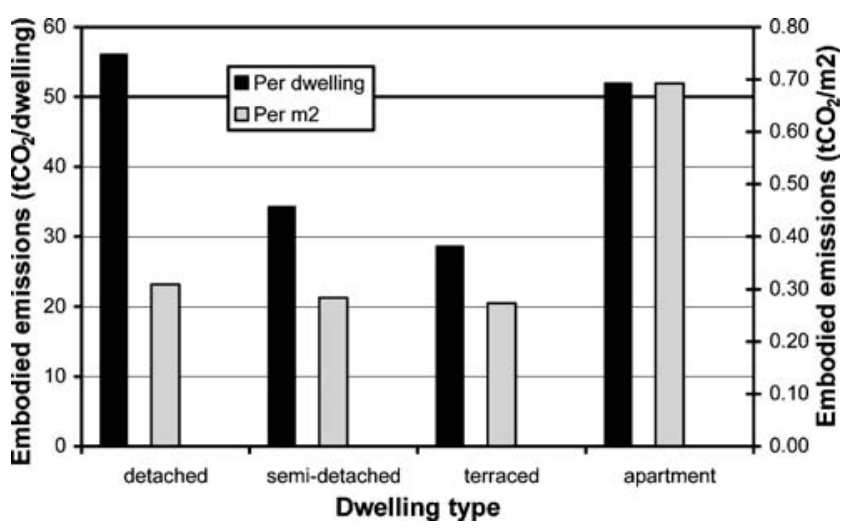

Fig. 3 Embodied $\mathrm{CO}_{2}$ for each dwelling type studied expressed both on a per dwelling and a per $\mathrm{m}^{2}$ of gross floor area basis

the highest embodied emissions due to their large size and construction characteristics. For example, the mean size of a detached house in the sample was $181.2 \mathrm{~m}^{2}$ whereas semi-detached houses, terraced houses and apartments were 120.6, 104.6 and $75.0 \mathrm{~m}^{2}$, respectively. Detached houses have greater construction materials' requirements since they have no shared walls, unlike other dwelling types. Apartments have the second highest embodied energy due to the need for more structural elements and, consequently, greater quantities of steel and concrete-both materials which have relatively high energy intensities. The use of these materials results in apartments producing the most $\mathrm{CO}_{2}$ emissions per constructed dwelling. Terraced houses were found to have the lowest embodied energy and $\mathrm{CO}_{2}$ emissions due to their relatively small size and use of shared structure (such as party walls). When compared on a per square metre of constructed gross floor area, it can be seen that due to their relatively small size and large structural requirements, apartments have almost two and a half times more embodied energy and $\mathrm{CO}_{2}$ emissions than other forms of residential construction.

Figure 4 shows the percentage of house type completed in 2006 by zone where it can be seen that areas closest to

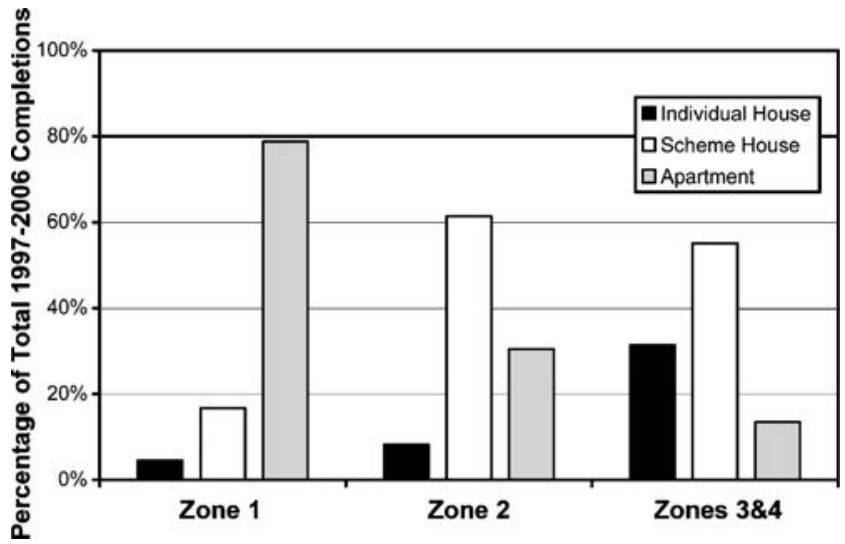

Fig. 4 Percentage of housing completions by type for each zone

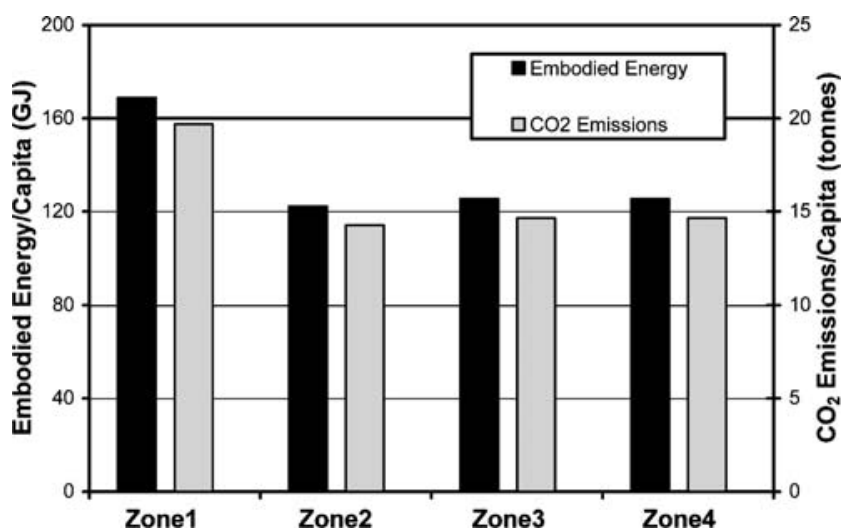

Fig. 5 Per capita embodied energy and construction-related $\mathrm{CO}_{2}$ emissions for each zone

urban centres had the highest concentration of apartment completions: almost four fifths of dwellings completed in the city centre were apartments while this figure fell to $16 \%$ in Zones 3 and 4 where the development of 'scheme houses' comprising mixed housing units dominated.

Based on the mix of dwellings completed in the 10-year period between 1997 and 2006 and on the average number of persons per household (CSO 2007a), average embodied energies and $\mathrm{CO}_{2}$ emissions were calculated for each zone and are shown in Fig. 5. It can be seen that both embodied energy requirements and $\mathrm{CO}_{2}$ emissions are highest in Zone 1 due to its high proportion of energy-intensive apartments and relatively low occupancy figures (2.5 persons per household compared to 3.0 for Zone 4).

\subsection{Transport}

It was found that the further a development is from the city centre, the greater the reliance on the private car while less trips are made using public transport. In Zone 1 some 31\% of trips are made by car compared to $49 \%, 58 \%$ and $63 \%$ for Zones 2, 3 and 4, respectively. The percentage of trips made by walking or cycling decreases with increasing distance from the city centre: for Zones 1,2 and 3 the

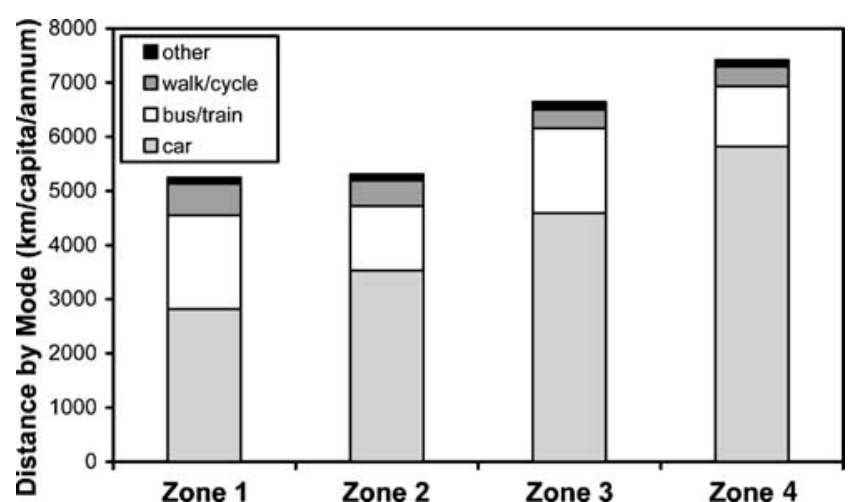

Fig. 6 Annual per capita distance travelled by mode for each zone 
Int J Life Cycle Assess

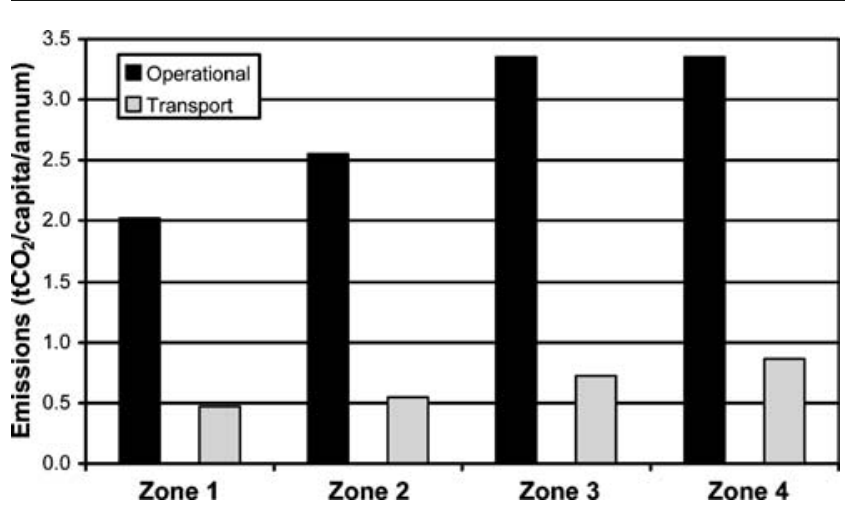

Fig. 7 Annual per-capita operational and transport-related $\mathrm{CO}_{2}$ emissions for each zone

461

462

463

464

465

466

467

468

469

470

471

472

473

474

475

476

477

478

479

480

481

482

483

484

485

486

487

488 percentages of trips made using these modes are $40 \%, 29 \%$ and $22 \%$, respectively. However, for Zone 4-commuter towns-the figure increases to $28 \%$ suggesting that local employment centres and amenities situated close to residential areas create greater opportunities for walking or cycling than in the Exurbs (Zone 3).

Figure 6 shows the annual modal distances travelled per capita for each zone. There is a clear positive relationship between distance from the centre of Dublin and distance travelled by car. The per capita distances travelled by public transport (bus and train) were highest for Zones 1 and 3 at $1,735 \mathrm{~km}$ and $1,566 \mathrm{~km}$, respectively and lowest for Zones 2 and 4 at 1,196 km and 1,119 km, respectively.

Not surprisingly, transport-related fuel consumption and $\mathrm{CO}_{2}$ emissions also increase the further a residential development is located from the city centre. Figure 7 shows the annual transport-related $\mathrm{CO}_{2}$ emissions per capita for each zone. It can be seen that annual transport emissions in Zone 4 were highest where the average person consumed 14.2 GJ of energy (equivalent to 4491 of petrol) and emitted $866 \mathrm{~kg}$ of $\mathrm{CO}_{2}$ in meeting their 2006 transport needs. These figures decrease with increased proximity to the city centre and reach a minimum of $8.3 \mathrm{GJ}$ and $472 \mathrm{~kg}$ $\mathrm{CO}_{2}$ for Zone 1. Transport-related $\mathrm{CO}_{2}$ emissions are therefore almost $85 \%$ higher for residential developments in the commuter towns than in the city centre and approximately $16 \%$ and $54 \%$ higher for suburban (Zone 2) and extra-urban (Zone 3) areas, respectively.

\subsection{Operation}

489

Results for the annual operational (heating, hot water and small power) energy requirements and associated $\mathrm{CO}_{2}$ emissions for four different dwelling types are shown in Table 2 both on a per square metre and per dwelling basis. Detached houses were found to emit $88 \mathrm{~kg} \mathrm{CO}_{2} / \mathrm{m}^{2} /$ annum of floor area; the corresponding figures for semi-detached houses, terraced houses and apartments were 67, 55 and $48 \mathrm{~kg} / \mathrm{m}^{2}$, respectively. Detached houses consume the greatest amounts of energy due to their higher floor areas and completely exposed external envelopes. Conversely, apartments have the lowest per dwelling consumption due to both their smaller size and reduced area of external envelope. Results were compared to emissions statistics for Scotland due to its similar weather and demographics; these are presented in Fig. 8. It can be seen that Scottish emissions compare favourably but are lower for detached and, to a lesser extent, semi-detached houses and are similar for terraced houses and apartments. These differences may be accounted for by the lower $\mathrm{CO}_{2}$-intensity of electricity production in Scotland and the relatively large sizes of detached and semi-detached houses constructed in the GDA over the period being analysed.

Figure 7 shows annual operational $\mathrm{CO}_{2}$ emissions per capita in each zone, taking account of the mix of house types and average occupancies for each zone. On average, each person in Zones 3 and 4 consumes approximately $85 \%$ more energy than in Zone 1 and 30\% more than in Zone 2 in order to heat and power their home. This is due to the dominance of detached houses in the exurbs and commuter towns and the greater concentration of apartments in the city centre and suburbs. This effect of housing type distribution on increasing per capita operational energy use in Zones 3 and 4 is offset to some degree by higher dwelling occupancy rates in these areas (3.0 per dwelling versus 2.5 for urban).

3.4 Maintenance and demolition

The average energy requirements associated with maintaining and improving a domestic dwelling were estimated
525

490

491 492 493 494 495 496 497 498 499 500 501 502 503 504 505 506 507 508 509 510 511

Table 2 Annual operational energy requirements and associated $\mathrm{CO}_{2}$ emissions for different dwelling types

\begin{tabular}{|c|c|c|c|c|c|c|}
\hline \multirow{2}{*}{$\begin{array}{l}\mathrm{t} 2.2 \\
\mathrm{t} 2.3\end{array}$} & \multirow[t]{2}{*}{ Dwelling type } & \multicolumn{2}{|l|}{ Energy requirements } & \multicolumn{2}{|l|}{$\mathrm{CO}_{2}$ output } & \multirow[t]{2}{*}{ Average size $\left(\mathrm{m}^{2}\right)$} \\
\hline & & (GJ/dwelling/year) & $\left(\mathrm{MJ} / \mathrm{m}^{2} /\right.$ year $)$ & ( $\mathrm{t} / \mathrm{dwelling} /$ year) & $\left(\mathrm{kg} / \mathrm{m}^{2} /\right.$ year $)$ & \\
\hline $\mathrm{t} 2.4$ & Apartments & 32 & 400 & 3.8 & 48 & 75 \\
\hline $\mathrm{t} 2.5$ & Terraced & 65 & 623 & 5.8 & 55 & 105 \\
\hline $\mathrm{t} 2.6$ & Semi-Detached & 92 & 763 & 8.1 & 67 & 121 \\
\hline $\mathrm{t} 2.7$ & Detached & 161 & 886 & 15.9 & 88 & 181 \\
\hline
\end{tabular}




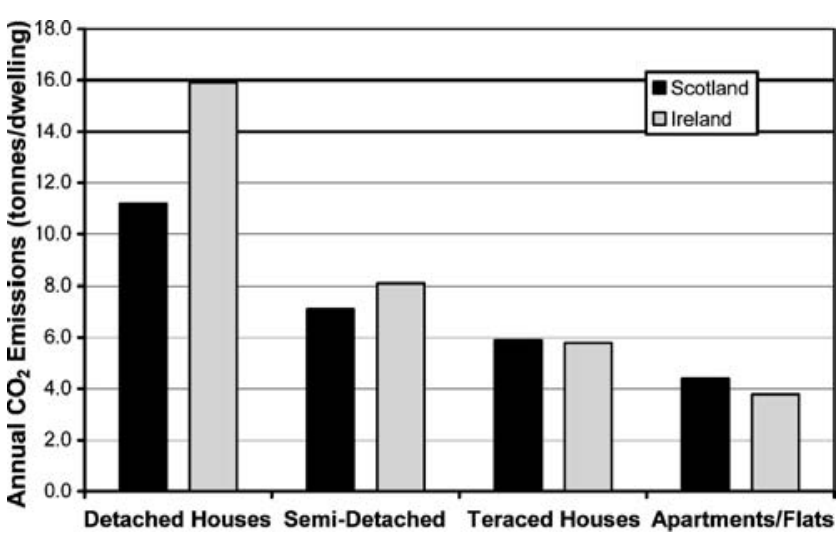

Fig. $8 \mathrm{CO}_{2}$ emissions per dwelling for Scottish housing stock and GDA sample (source: Hinchliffe 2005) using input-output analysis (as described in Section 2.5) to be $0.046 \mathrm{GJ} / \mathrm{m}^{2} /$ annum producing $6.8 \mathrm{~kg} \mathrm{CO} / \mathrm{m}^{2} /$ annum. Due to a lack of data it was not possible to differentiate between maintenance requirements for different dwelling types. It is likely that this aggregation problem underestimates maintenance energy requirements for detached and semi-detached houses given the greater opportunities for the major refurbishment and extension of such properties over apartments and-to a lesser extentterraced houses. Therefore, in the absence of more disaggregated data, the same per square metre energy and $\mathrm{CO}_{2}$ emissions intensities were applied to the average house size for each zone.

The cost of demolishing a typical $120 \mathrm{~m}^{2}$ domestic dwelling (brick, block and timber floor construction) was estimated at $€ 17,500$ in 2004 and the energy intensity for Nace 45.1 was calculated to be $2.25 \mathrm{MJ} / €$ of demolition expenditure. Combining these figures gives a housing demolition energy requirement of approximately $0.33 \mathrm{GJ} / \mathrm{m}^{2}$ with associated emissions of $8.3 \mathrm{~kg} \mathrm{CO} / \mathrm{m}^{2}$. The additional cost of demolishing the concrete or steel structure in an apartment is estimated to be approximately $€ 14,300$, resulting in an apartment demolition energy intensity of $0.60 \mathrm{GJ} / \mathrm{m}^{2}$ with associated emissions of $15.1 \mathrm{~kg} \mathrm{CO} / \mathrm{m}^{2}$. These figures do not allow for recycling.

\subsection{Life cycle}

Figure 9 shows the $\mathrm{CO}_{2}$ emissions for a residence built in the last 10 years in each of the four zones in the GDA. This assumes a building lifespan of 100 years. On average Zone 3 and 4 occupants consumed $92-98 \%$ more energy than those in Zone 1 and approximately one third more than Zone 2. Per capita $\mathrm{CO}_{2}$ emissions in Zones 3 and 4 were approximately $50-55 \%$ greater than Zone 1 and almost $33 \%$ greater than Zone 2 . The higher $\mathrm{CO}_{2} /$ energy ratio in Zone 1 can be accounted for by the high incidence of $\mathrm{CO}_{2}-$ intensive electrical storage heating in Zone 1 apartments.

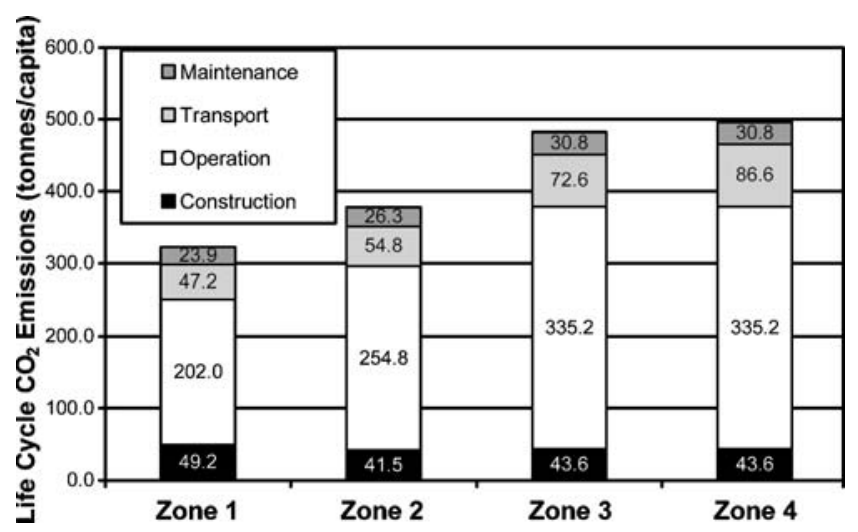

Fig. 9 Life cycle component $\mathrm{CO}_{2}$ emissions for each zone (demolition has been excluded since emissions are negligible compared to other life cycle stages)

Figure 10 shows $\mathrm{CO}_{2}$ emissions for each dwelling type excluding transport but including the construction, operation and maintenance life cycle stages (demolition has been excluded since these emissions are negligible). It can be seen that operational emissions dominate and that total emissions over 100 years are significantly higher for detached houses $(1,773 \mathrm{t})$ than for semidetached $(929 \mathrm{t})$, terraced $(680 \mathrm{t})$ and apartments $(482 \mathrm{t})$. This is due to the greater electrical and space heating requirement associated with the large floor areas of detached houses in Ireland and their relatively greater exposed-envelope/volume ratios. These figures demonstrate significant benefits in promoting high-density spatial planning policies.

When the data for all zones are aggregated, operational requirements dominate accounting for $68 \%$ of all $\mathrm{CO}_{2}$ emissions followed by transport at $17 \%$, construction at $9 \%$ and maintenance at $6 \%$. Demolition contributes to less than $0.5 \%$ of life cycle emissions.

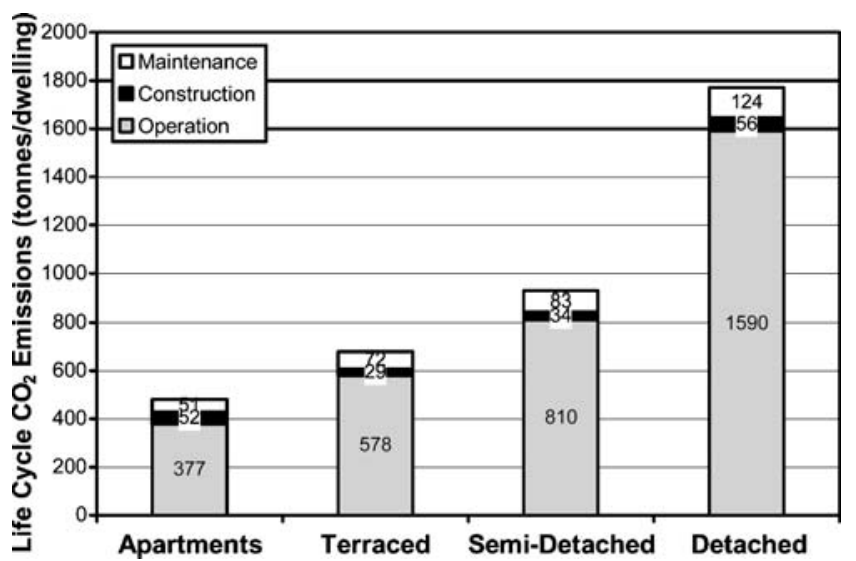

Fig. $10 \mathrm{CO}_{2}$ emissions for each dwelling type excluding transport (demolition has been excluded since emissions are negligible compared to other life cycle stages) 


\section{Conclusions}

The life cycle per capita $\mathrm{CO}_{2}$ emissions in the GDA are approximately 50-55\% greater in the exurbs and commuter towns than in the city centre; corresponding energy intensities vary by almost $100 \%$. Per capita residential emissions over a 100-year life span taking into account construction, operational, transport, maintenance and demolition energy requirements were 323, 378, 482 and 496 tonnes, respectively for the urban, suburban, extraurban and commuter town zones studied.

Of the five life cycle stages studied, operational energy requirements (predominantly space heating and hot water, but including power) contributed most significantly to emissions $(68 \%)$, followed by transport $(17 \%)$, construction (9\%) and maintenance/renovation (6\%); demolition was found to have a negligible effect. Annual per-capita operational emissions in Zones 3 and 4 were almost twice as great as those in Zone 1 both due to larger dwelling sizes and the predominance of detached and semi-detached dwellings (with large amounts of exposed walls) in the former and the predominance of smaller apartments in the latter. The car dominated as the preferred mode of transport in all zones; however, this was most pronounced in the zones furthest from the city centre (zones 3 and 4) where per capita emissions were almost twice those of residents in the city centre. It is interesting to note that despite their smaller size, the per capita construction energy intensities of apartments were approximately one third greater than for traditional detached, semi-detached and terraced residences due to the greater energy intensity of the structure. However, this difference was more than compensated for by the significantly lower operational emissions referred to above.

By 2006 residential development in the GDA completed over the 10 years up to and including that year was contributing 3,434 $\mathrm{kt} \mathrm{CO}$ /annum-representing $4.9 \%$ of national emissions for that year; this comprised 2,108 tonnes of recurrent emissions (operational, transport, maintenance) and 1,325 kt of once off construction-related emissions. Had the development policy required Zone 1-type development and transport modes, then emissions for the year 2006 would have been $2,892 \mathrm{kt} \mathrm{CO}_{2}$ - a reduction of almost $16 \%$ over the actual figure and representing approximately $4.1 \%$ of national emissions. However, in this scenario recurrent emissions would have been reduced to $1,417 \mathrm{kt} \mathrm{CO}_{2}-$ a reduction of $33 \%$ over actual levels.

\section{Recommendations and perspectives}

Irish and other governments' residential sector energy policies tend to focus on minimising operational energy use and emissions. This approach is broadly supported by the findings of this paper that approximately two thirds of emissions arise from heating and powering dwellings in the GDA. However, although operational $\mathrm{CO}_{2}$ emissions dominate those from transport, maintenance and construction, assessing only operational emissions would underestimate 100 -year emissions by approximately one third. This demonstrates the benefits of LCA in evidence-based policymaking and highlights the need for policy measures targeted at mitigating non-operational emissions. Indeed, the relative importance of these emissions will increase as existing energy policies further reduce operational emissions.

An additional weakness of existing policies is the emphasis placed on reducing unit area emissions through energy efficiency measures. In Ireland, this policy has run concurrently with the development of large detached dwellings in the area studied. However, the results above clearly indicate that large, detached dwellings achieve national emissions policy objectives despite having a significantly higher environmental impact than smaller 'attached' dwellings such as apartments. Although other social and functional considerations must be taken into account, a policy favouring high-density residential development with more modest floor areas would reduce emissions. Such a 'high density' planning approach would have the added benefit of reducing car dependency since residences could be constructed closer to urban centres and public transport infrastructure with relatively low emissions intensities. The operational and transport emissions from the worst performing zones could be reduced by approximately $40 \%$ with suitable policies.

Acknowledgement The author wishes to thank for the support of those who assisted in providing data for this work: the Pierse Group, Dublin Transportation Office, CODEMA, and Sustainable Energy Ireland. Funding for this work was provided by the Dublin Institute of Technology's Research Support Unit.

\section{References}

Acquaye A, Duffy A, Basu B (2008) Development of a construction sub-sector embodied energy hybrid analysis. Faculty of Engineering, Dublin Institute of Technology. Working Paper 1. http:// arrow.dit.ie/dubenart/1

Bullard C, Penner P, Pilati D (1978) Net energy analysis—handbook for combining process and input-output analysis. Resour Energ $1: 267-313$

Castro M, Remmerswaal J, Reuter M (2003) Life cycle impact assessment of the average passenger vehicle in the Netherlands. Int J Life Cycle Assess 8(5):297-304

Cox J, Hickman A (1998) Aggregated emission factors for road and rail transport, report for MEET project: methodologies for estimating air pollutant emissions from transport. TRL, Berkshire

Crawford RH (2007) Validation of a hybrid life-cycle inventory analysis method. J Environ Manage (in press), Corrected Proof, viewed 7
632

633

634

635

636

637

638

639

640

641

642

643

644

645

646

647

648

649

650

651

652

653

654

655

656

657

658

659

660

661

662

663 665 666 667 668

670 671 672 673 674 675 676 677 678 679 680 681 682 683 684
664 
685

686

687

688

689

690

691

692

693

694

695

696

697

698
Frank LD, Stone B, Bachman W (2000) Linking land use with household vehicle emissions in the central Puget sound: methodological framework and findings. Transport Res Part D. 5(3):173-196

Hammond G, Jones C (2006) Inventory of Carbon and EnergyVersion 1.5 Beta, University of Bath, UK. Accessed 26 August 2008, http://people.bath.ac.uk/cj219/

Hinchliffe S (2005) Scottish housing condition survey: energy efficiency and estimated emissions from the Scottish Housing Stock 2003/04, Scottish Executive. Viewed 3 October 2008, http://www.scotland.gov.uk/Resource/Doc/161328/0043785.pdf

Howley M, O’Leary F, Ó Gallachóir B (2006) Energy in Ireland 1990-2005. Sustainability Energy Ireland, Dublin, pp 67-73

Næss P (2006) Accessibility, activity participation and location of activities: exploring the links between residential location and travel behaviour. Urban Stud 43(3):627-652

Netherlands Ministry of Housing, Spatial Planning and the Environment (2004) Sustainable refurbishment of high-rise residential buildings and restructuring of surrounding areas. Report for European Housing Ministers' Conference held in Prague, Czech Republic 14-15 March 2005. Viewed 22 January 2008, www.eukn.org/ eukn/themes/Urban_Policy/Housing/Housing_quality/SustainableRefurbishment-of-High-Rise-Residential-Buildings_1001.html

Newman P, Kenworthy J (1999) Sustainability and cities: overcoming automobile dependence. Island, Washington, pp 31-36

SEI (2004) Strategies to reduce greenhouse gases from Irish transportation. SEI, Dublin. Viewed 18 May 2007, http://www.sei.ie/ uploadedfiles/InfoCentre/GHGtransportFNLformattedcover04.pdf

SEI (2005) Energy consumption and $\mathrm{CO}_{2}$ emissions in the residential sector 1990-2004. Viewed 22 May 2007, www.sei.ie/index.asp? locID $=70 \&$ doc $I D=-1$

SEI (2006) Energy in transport: trends and influencing factors. SEI, Dublin

Yohanis YG, Norton B (2002) Life-cycle and embodied energy for a generic single-storey office building in the UK. Energy 27:7792 
ID: $11367 / 59$.

\section{AUTHOR QUERY FORM}

Dear Author,

During the preparation of your manuscript for typesetting, some questions have arisen. These are listed below. Please check your typeset proof carefully and mark any corrections in the margin of the proof or compile them as a separate list.

\section{Queries and/or remarks}

Location in Article Query/Remark

No queries.

Thank you for your assistance. 